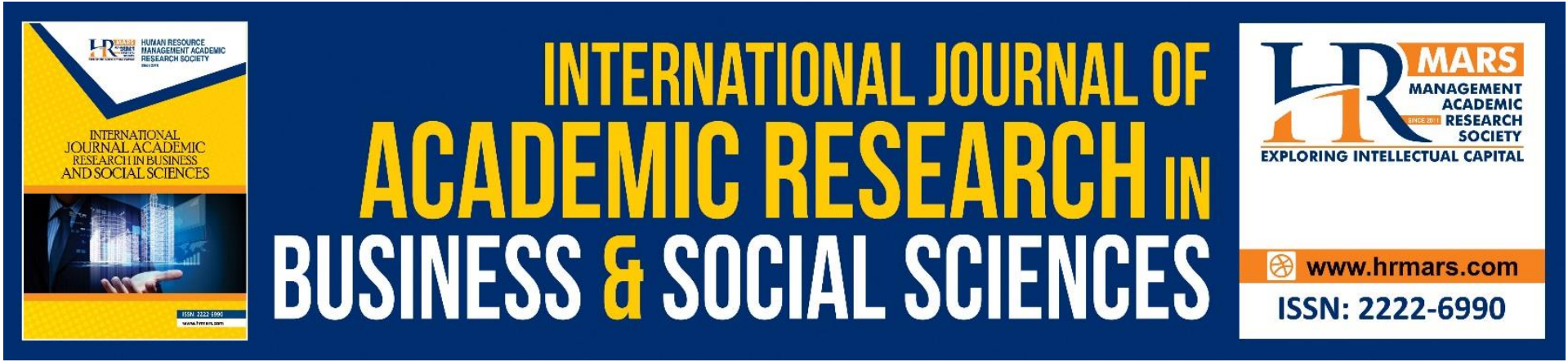

\title{
Teacher Attitude towards the Implementation of Programme of Pastoral Instruction.
}

\author{
Judith Jemutai Tanui, Ruth Andambi, Jacob Lolelea Natade
}

To Link this Article: http://dx.doi.org/10.6007/IJARBSS/v11-i5/9844

DOI:10.6007/IJARBSS/v11-i5/9844

Received: 01 March 2021, Revised: 05 April 2021, Accepted: 26 April 2021

Published Online: 05 May 2021

In-Text Citation: (Tanui et al., 2021)

To Cite this Article: Tanui, J. J., Andambi, R., \& Natade, J. L. (2021). Teacher Attitude towards the Implementation of Programme of Pastoral Instruction. International Journal of Academic Research in Business and Social Sciences, 11(5), 1-12.

Copyright: (c) 2021 The Author(s)

Published by Human Resource Management Academic Research Society (www.hrmars.com)

This article is published under the Creative Commons Attribution (CC BY 4.0) license. Anyone may reproduce, distribute, translate and create derivative works of this article (for both commercial and non-commercial purposes), subject to full attribution to the original publication and authors. The full terms of this license may be seen at: http://creativecommons.org/licences/by/4.0/legalcode

Vol. 11, No. 5, 2021, Pg. 1 - 12

http://hrmars.com/index.php/pages/detail/IJARBSS

JOURNAL HOMEPAGE

Full Terms \& Conditions of access and use can be found at http://hrmars.com/index.php/pages/detail/publication-ethics 


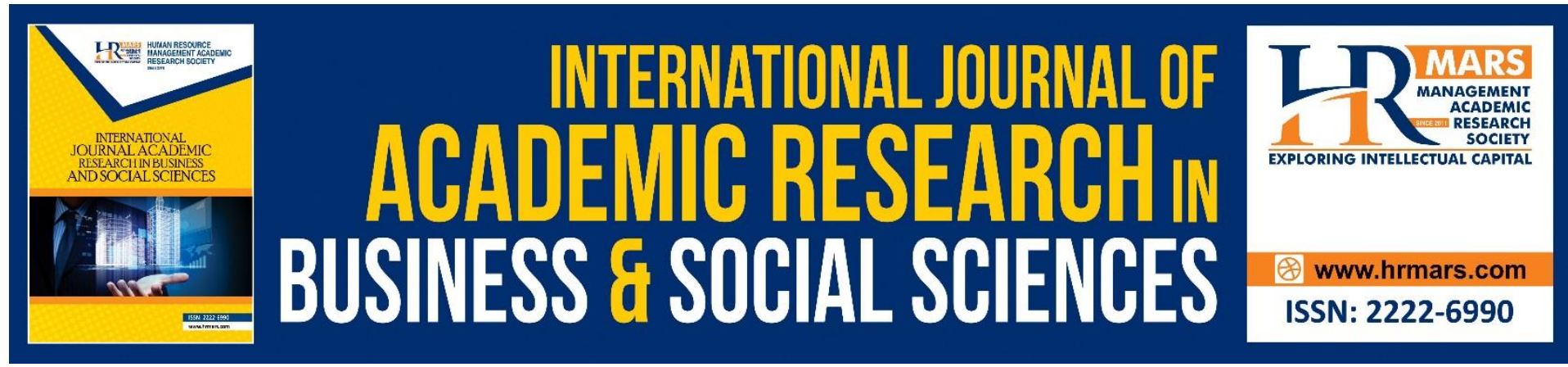

\title{
Teacher Attitude towards the Implementation of Programme of Pastoral Instruction.
}

\author{
${ }^{1}$ Judith Jemutai Tanui, ${ }^{2}$ Dr. Ruth Andambi, ${ }^{3}$ Dr. Jacob Lolelea \\ Natade \\ ${ }^{1}$ Master of Education in Religious Education, ${ }^{2}$ Lecturer University of Eldoret, ${ }^{3}$ Lecturer \\ University of Eldoret
}

\begin{abstract}
Programme of Pastoral Instruction (PPI) is perceived as an easy subject needing little teaching because it is a mere extension of church services and the Bible. This leads to a negative attitude towards the subject. The attitude of teachers towards a subject affect how a programme is implemented. Some teachers in primary schools have a perspective that the programme of pastoral instruction is a source of disunity. The study sought to establish teacher attitude towards the implementation of the programme of pastoral instruction. The study was guided by Motivator-Hygiene theory. The study employed a descriptive survey research design. A simple random sampling technique was used to select fourteen catholic sponsored primary schools in Marakwet West Sub-County Elgeyo Marakwet County. All headteachers of the sample schools participated in the study. A simple random sampling technique was used to select 42 PP1 teachers and 272 pupils in the upper primary school, class 6,7 and 8. Data were collected using questionnaires. Data analysis was done using descriptive statistics, including percentages, means, frequency and tables. The findings revealed that fifty-two percent (52\%) of the respondents strongly disagreed that pastoral instruction has overcrowded the timetable. The study concludes that teachers' working conditions needed a boost by providing them with incentives to improve their morale. There is also a need to recognize and appreciate the efforts of teachers by rewarding them. The study recommends that: there is a need for teachers to undergo training. This is based on the fact that teachers who have adequate training on instructional resource use influence preschool learners' achievement in both examinable subjects as well as non-examinable ones.

Keywords: Teacher, Attitude, Instruction, Pastoral Instruction, Resources
\end{abstract}

\section{Background to the Study}

Religion is regarded as one of the external agencies of morality that help humans to make moral decisions. Religion could enable the learner to look towards humanity's final goal and destiny (Rivas, 2012). It is the most binding moral agency because of its transcendent authority. Religious education aims to transform an individual's life into the right relationship with God, fellow men, and both his/her physical and cultural environment. It offers supernatural assistance to help a human person make a rational decision. Religious education has been identified as an important curriculum area in the transmission of desirable values. 
Modern education can be traced to Christian missionaries. They were responsible for the majority of schools until independence. With the attainment of independence, the circumstances changed. There was concern about religious education within a secular state, with a diverse and complex religious scene (Chemutai, 2015). Under Ominde (1964), the education committee was given the task to review and make recommendations on education in newly independent Kenya. In section 72 of the Ominde Report (1964) rejected both the establishment of a state religion and a purely secular state for Kenya. It stated that religious education be offered and taught in primary schools as an academic subject based on acceptable educational criteria. When a common syllabus for CRE was formed in 1972, the church wished to offer specific church teachings to their followers in primary schools that were used to form the Programme of Pastoral Instruction (Odongo, 2011).

The effort towards a joint syllabus was partly realized in 1972 when an interim joint syllabus was approved O'Donoghue, \& O'Donoghue (2004). The specific protestant and Catholic teachings formed a new syllabus known as Programs of Pastoral Instruction. By 1978 three such programs had been developed; Catholic in1972, Protestant in 1975 and Seventh Day Adventist in 1978. The Kenya Episcopal Conference developed a syllabus for teaching the Catholic Program of Pastoral Instruction with the following specific objectives; to develop commitment and appreciation to the Catholic belief, practice and mission, appreciate God as a loving Father to whom they can respond in faith, love and admiration and Play an active role in the gospel commission and Christian service to humankind (Orabator, 2009).

The Ominde Commission recommended that churches produce syllabus A and B for teaching Religious Education in Protestant and Catholic schools, respectively. Each syllabus had the common Christian beliefs that are upheld by all the Christian churches and specific denominational beliefs and practices. The Catholic Church, for example, upholds praying through the Virgin Mary, and adherents also use the rosary to pray, which the protestant churches do not (Winston, 2008). However, following the enactment of the Education Act (1968), schools that were hitherto denominational became public (Odongo, 2011).

Each and every Program of Pastoral Instruction lesson had two specific objectives guiding the teacher on what to teach. The Cognitive objective (knowledge objective) states what knowledge or information learners could gain by the end of a lesson. The effective objective states what attitudes, values, and virtues the leaner could develop. The teacher prepares the lesson by reading and comprehending a given text from the Bible, prepares a poster, picture, a chart or a dramatized song (Klein and Blomberg, 2017). Teachers have the responsibility matched by their creativity to improvise materials, depending on their situation and environment. The Diocesan Religious Education Advisor (DREA) may be consulted by the interested teachers of PPI about the resources available, for example, textbooks in local languages, appropriate posters and other appropriate spiritual books (Larson, 2019).

According to Koech (2014), pastoral instruction is seen as a simple subject requiring little teaching, and it is a mere extension of church service and the Bible. This results in a negative attitude towards the subject. Teachers' attitude towards a subject affect how a programme is implemented. Some teachers in primary schools have a perspective that the programme of pastoral instruction is a source of disunity. These teachers suppose that the most suitable people to teach pastoral instruction are pastors and priests. While others view PPI as an extra duty given to them, they are already too heavily burdened with the pressing demands of the 8-4-4 education curriculum.

In view of the Catholic Teacher Association (CTA) deliberations in Marakwet West (2011), it was vivid that there was inadequate training since the cost of training by TPC and CISRET is 
high for individual teachers. It was observed that there was no follow up by the employer, Ministry of Education, and the sponsor in the implementation of PPI. As a result, teachers who are non-Catholic use the lessons allocated for PPI for other subjects. Similarly, the school administrators who are non-Catholic do not offer much material support in terms of teaching and learning material resources. It was further reported that pupils are normally very reluctant during PPI lessons because not all pupils come from catholic backgrounds and more so that the subject is not examinable, minimizing the desired outcome. In view of the deliberations of CTA in Marakwet West (2011), there is an indication of lack of structure, form and content of PPI, which manifests itself in a de-motivated teacher and is a drawback to its implementation.

\section{Statement of Problem}

Religious education has been identified as an important curriculum area in the transmission of desirable values. Program of Pastoral Instruction (PPI) was an integral part of religious education, but with a Pastoral approach (Muthamba, 2017). Program of Pastoral Instruction as religious instruction was meant to help pupils become better members of their respective churches. The implementation of the Program of Pastoral Instruction encounters a lot of criticism and challenges since the teachers perceive that they are already too heavily burdened with the demands of the 8-4-4 education curriculum, and they consider it as an extra work since it is not examined at the end of the primary school cycle (Munishi, 2016). However, changes in the Education Act on school sponsorship seem to be causing some misunderstanding between sponsors, community, teachers and the Government Mabeya et al., (2010). Some sponsors have been accused of interfering with the schools' core business by closing down schools indefinitely. In other instances, some have rejected and even evicted headteachers posted to schools by the Teachers Service Commission (Cheruiyot, 2011). According to Gikandi (2015 some sponsors meddling in schools destabilize the instructive activities in the system. It is against this background that the current study focused on establishing teacher attitude towards the implementation of Programme of Pastoral Instruction in Marakwet West Sub-County, Elgeyo Marakwet County.

\section{Specific Research Objective}

The study was guided by the following research objective:

i. To determine teacher attitude towards the implementation of Programme of Pastoral Instruction.

\section{Specific Research Question}

i. What are the teacher's attitudes towards the implementation of Programme of Pastoral Instruction?

\section{Theoretical Framework \\ Motivator-Hygiene Theory}

The study was guided by Herzberg's (1959) two -factor theory known as Motivator-Hygiene Theory. American Frederick Herzberg (1923-2000) was one of the most influential management teacher and consultant of the post-war era. The 'Father of Job Enrichment' challenged thinking on work and motivation and conducted a widely-reported motivational 
study on accountants and engineers to develop two-factor theory, the theory was further advanced by Malik and Naeem (2013).

Herzberg's based the research on in-depth interview techniques, known as a critical incident technique. One problem with this approach is that respondents generally associated good times with things under personal control, or for which they could give themselves credit. Bad times, on the other hand, were more often associated with factors in the environment, under the control of management. Herzberg concluded those jobs satisfiers are related to job content and job dissatisfies are allied to job context. Herzberg labeled satisfiers motivators and called dissatisfies hygiene factors.

The hygiene factors, which are mostly concerned with the work environment, can be explained through Abraham Maslow's (1996) Hierarchy of Needs. Maslow was a famous American psychologist who determined that some human needs take precedence over others. Beyond the details of air, water, food and sex, Herzberg laid out five broader layers: the physiological needs, the need for safety and security, the need for love and belonging, the need for esteem, and the need to actualize the self, in that order.

The first three needs physiological, safety and social are all in the hygiene factor of Herzberg's Theory. This informs that the hygiene needs are generally the basic needs of individuals. This compatibility of Herzberg's Theory and the Hierarchy of Needs proves that Herzberg's Theory is different from Maslow's only in the method of categorization.

Herzberg categorizes basic needs of human beings as hygiene factors. This means basic needs do not give motivation but merely create a conducive work environment. There would be no dissatisfaction among workers when basic needs are fulfilled, but it does not motivate them or give them satisfaction; it merely removes dissatisfaction.

The motivation factors are esteem and self-actualization needs. These needs, when fulfilled, would give a teacher satisfaction. Before satisfaction can actually be achieved, there must not be any element of dissatisfaction.

Thus, it is easier to actually apply Herzberg's Theory (1959) coupled with Maslow's (1943) Hierarchy of Needs. This serves to strengthen Herzberg's Theory as it simplifies its application as a strategy to motivate employees. By identifying the needs in Maslow's hierarchy, the hygiene and motivation factors can be obtained and subsequently fulfilled. Herzberg recognizes that true motivation comes from within a person and not from the environment, or external factors.

The presence of hygiene factors according to Cohen (2007) does not cause satisfaction and do not increase performance of workers. Hygiene factors include: company policy and administration, technical supervision, salary, interpersonal relationship with the supervisors and work conditions. All these factors are associated with job context. These factors are necessary but not sufficient conditions for the satisfaction of workers. According to Cohen (2007) if hygiene factors are allowed to deteriorate, a climate of dissatisfaction, tension, frustration and friction will prevail and workers will not perform their best.

Motivators on the other hand include achievement which is the drive to excel and accomplish challenging tasks and achieve a standard of excellence, recognition, the work itself, responsibility and prospects for career advancement. Motivators are associated with the job content or what workers actually do in their work. Cohen (2007) pointed out that dissatisfaction is not the opposite of satisfaction but both hygiene and motivation factors are important in different ways.

Highly motivated and satisfied teachers can create a conducive social, psychological and physical climate in the classroom to implement PPI. Exemplary teachers appear able to 
integrate professional knowledge (subject matter and pedagogy), interpersonal knowledge (human relationships) and intrapersonal knowledge (ethics and reflective capacity) when they are satisfied with the job Vansteenkiste et al (2019).

Further, a teacher's commitment to teaching at their work place has been found to be enhanced by psychic rewards (acknowledgement of teaching competence), meaningful and varied work, task autonomy and participatory decision-making, positive feedback, collaboration, administrative support, reasonable work load, adequate resources and pay and learning opportunities providing challenging task and accomplishment Meece et al., (2016). On the other hand, extrinsic incentives such as merit pay or affecting teaching rewards have not been found to effect teacher job satisfaction and effectiveness. According to Bissessar (2014), pay incentives have been found to be unsuccessful in increasing motivation. In their studies of 167 teachers, Sylvia and Hutchison (1985) concluded that:

'Teacher motivation is based in the freedom to try new ideas, achievement and appropriate responsibility levels and intrinsic work elements...based upon our finding, schemes such as merit pay were predicted to be counterproductive.'

They regarded that true job satisfaction is derived from the gratification of higher order needs, "social relations, esteem and actualization" rather than lower-order needs. The extrinsic factors evolve from the working environment while the actual satisfiers are intrinsic and encourage a great effectiveness by designing and developing teachers' higher-level needs. However, several researchers are of the opinion that if educational administrators and policy makers understand teacher's job satisfaction needs, they can design a reward system to satisfy both the teacher and the educational goals. Nwanchukwu (2006) was of the opinion that "however highly motivated to perform a teacher may be, they need to possess the necessary ability to attain the expected level of performance."

The theory is applicable to this study in that teacher's motivation to implement PPI is primarily influenced by psychic rewards such as acknowledgement of teaching competence, meaningful and varied work, task autonomy and participatory decision-making, positive feedback, collaboration, administrative support, reasonable work load, adequate resources, pay and learning opportunities providing challenging task and accomplishment. Herzberg's Theory allows for the shaping of a teacher's job needs, motivation and can be used to modify teachers needs profile

\section{Literature Review}

This section covers theoretical review, empirical review and conceptual framework.

\section{Attitudes of Teachers Towards Teaching of PPI}

Attitudes are the learned predisposition to respond positively or negatively to certain objects, situations, institutions or persons. As such, attitudes constitute the cognitive, affective and performance components. The attitude of teachers toward a programme affects the way the programme is implemented. Linda Rikard (2016) pointed out that attitude also affect pupils' fitness for various curricula activities and that unless a pupil has a favorable attitude towards a set of instructional objectives and sets them over as desirable goals for himself, the additional processes were relatively ineffective. They go further to define attitude as a feeling towards something or somebody and that the attitude of the pupil depends on the role of the teacher. (Odongo, 2011) underscores the need to change people's attitudes to favorable implementation of any particular innovation. When he points out that, in the very simplest analysis, the task of curriculum implementation can be said to involve changing the attitude 
of policy makers, administrators, parents, and ultimately the learners. In addition, Gross, (2004) emphasized the need for the staff to be willing to expand their time and effort required for this implementation and this condition must be operative.

According to Walkington (2012) initiating a curriculum change encompasses human engineering, a strategy of modifying attitude and feeling, which often is a task of producing competence for curriculum development. To him professional skills and attitude go hand in hand each affecting the other. These authors neglect the impact of policy and administration on attitude as teachers simply adopt the prevailing attitude towards PPI from their superiors and the policy environment which this study extensively addressed.

A study carried out by Avramidis (2007) on the availability of resources for teaching PPI reveal that teachers had a positive attitude towards the subject and this had bearing of its successful implementation. Positive attitude towards an innovation not only influences the willingness of people involved to implement but also the pupils' willingness to learn. In the same way, a negative attitude impairs the motivation of implementers and learners. In 1985, PPI syllabus was revised, since then; Major changes have taken place in the content and structure of education of which PPI is part.

According to Adongo (2009) since these changes were made, PPI has not been taken seriously in primary schools. PPI is not examined in the national examination at the end of primary school cycle. Most teachers use the period of PPI to teach subjects which are examined at national level. Many people think that pastoral instruction is an easy subject needing little teaching being a mere extension of church services and the Bible. This leads to a negative attitude towards the subject. The attitude of teachers towards a subject affects the way the programme is implemented. Some teachers in primary schools see programme of pastoral instruction as a source of disunity. These teachers think that, the most suitable people to teach pastoral instruction are pastors and priests. While others see PPI as an extra duty given to them, yet they are too heavily burdened with the pressing demands of the 8.4.4education curriculum. Pupils also think PPI is a waste of time. From January 2003 anew curriculum whose aim is to reduce the workload for both teachers and pupils was implemented.

\section{Conceptual Framework}

The conceptual framework in Figure 1 below is a simplified example of teacher's attitude as the independent variable while implementation of PPI is the dependent variable.

\section{Independent variable}

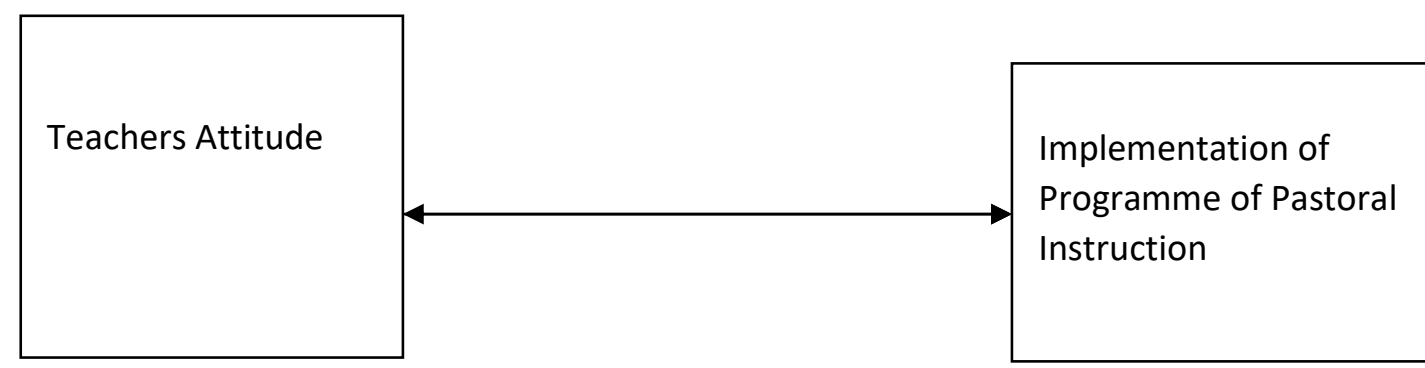

Source: Author (2020)

Figure 1 Conceptual Frameworks: The relationship between Independent, moderating and Dependent variables 


\section{Research Methodology \\ Research Design}

The study employed a descriptive survey design. Survey design collects data on various variables found in the system and deals with incidences and relationships (Mitchell \& Jolley, 2012).

\section{Study Area}

The study was carried out within Marakwet West Sub-County in Elgeyo Marakwet County, Kenya.

\section{Study Population}

The target population of the study comprised mainly of 42 teachers (three from each school) who teach programme of pastoral instruction, 14 head teachers ( 1 from each school), 907 pupils (class $8=292$, class $7=302$ and class $6=313$ ), 1 SCDE, and 1 Quality Assurance and Standards Officer within the Sub-County.

\section{Sampling and Sampling Procedures}

Purposive, stratified and simple random sampling procedures were used in selecting the required sample for this study. Schools were first categorized into Catholic and Non-Catholic Sponsored schools within the Sub-County. Simple random sampling was used to select the schools within the Sub-County. Purposive sampling was used to select 14 head teachers, 1 SCDE and QASO's on the implementation of the curriculum. The researcher sampled $30 \%$ of the learners from each class, in a descriptive research; a sample size of $10-50 \%$ is acceptable (Mugenda \& Mugenda, 1999).

\section{Data Collection Instruments}

The researcher used questionnaire. A comprehensive questionnaire with open and closed ended questions was administered to the respondents. Open-ended questions were used in order to provide opportunities for flexibility and inclusion of the respondents' options and opinions.

\section{Piloting of Research Instruments}

The catholic sponsored schools within Marakwet West Sub County not in the sample were used for pilot testing. A Pilot study was carried out in order to determine the questionnaires and interview questions internal consistency and to detect any difficulties that the respondents might likely to face when responding to the items. Errors were corrected and necessary amendments made. The instrument showed consistent results and therefore considered to be reliable.

\section{Data Analysis Procedures}

After data collection, responses from all items were crosschecked to facilitate coding and processing for analysis using Statistical Programme for Social Sciences (SPSS) computer package version 20. Descriptive statistics such as frequency distribution, percentages and means were calculated. Data was presented using frequencies and percentages on graphs, charts and tables. 


\section{Research Findings and Discussions}

This section presents data analysis results, interpretations and discussions.

\section{Teachers Attitude towards Implementation of Programme of Pastoral Instruction}

The first research question was to investigate teacher's attitudes towards the implementation of programme for pastoral instruction. On A Likert scale of 1-5 where 1 represents strongly disagreed and 5 represents strongly agreed, the respondents were asked to indicate their agreement with the statement.

Table 1 Teachers Attitude towards Implementation of Programme for Pastoral Instruction

\begin{tabular}{|c|c|c|c|c|c|c|}
\hline Statement & & SA & A & $\mathbf{U}$ & D & SD \\
\hline \multirow{2}{*}{$\begin{array}{l}\text { Instead of buying resource } \\
\text { materials for P.P.I they could buy } \\
\text { more for examinable } \\
\text { subjects }\end{array}$} & $F$ & 20 & 5 & 4 & 5 & 8 \\
\hline & $\%$ & 48 & 11 & 9 & 13 & 19 \\
\hline \multirow{2}{*}{$\begin{array}{l}\text { Programme for pastoral instruction } \\
\text { could be taught in churches }\end{array}$} & $\mathrm{F}$ & 9 & 23 & 0 & 4 & 6 \\
\hline & $\%$ & 21 & 55 & 0 & 9 & 15 \\
\hline \multirow{2}{*}{$\begin{array}{l}\text { Programme for pastoral instruction } \\
\text { has overcrowded the timetable for } \\
\text { nothing }\end{array}$} & $\mathrm{F}$ & 5 & 10 & 0 & 5 & 22 \\
\hline & $\%$ & 12 & 24 & 0 & 12 & 52 \\
\hline \multirow{2}{*}{$\begin{array}{l}\text { It is never possible to teach all topics } \\
\text { in P.P.I because of inadequate } \\
\text { resources }\end{array}$} & $\mathrm{F}$ & 23 & 6 & 4 & 0 & 9 \\
\hline & $\%$ & 55 & 15 & 9 & 0 & 21 \\
\hline \multirow{2}{*}{$\begin{array}{l}\text { P.P.I is exciting and enjoyable to } \\
\text { teach }\end{array}$} & $\mathrm{F}$ & 18 & 10 & 3 & 5 & 6 \\
\hline & $\%$ & 42 & 24 & 8 & 12 & 14 \\
\hline \multirow{2}{*}{$\begin{array}{l}\text { If P.P.I is not examined at K.C.P.E } \\
\text { level then there is no need to be } \\
\text { taught. }\end{array}$} & $\mathrm{F}$ & 9 & 10 & 6 & 17 & 0 \\
\hline & $\%$ & 20 & 24 & 15 & 41 & 0 \\
\hline \multirow{2}{*}{$\begin{array}{l}\text { Teachers need in-service training } \\
\text { and seminar courses to be able to } \\
\text { effectively implement the P.P.I } \\
\text { education programme. }\end{array}$} & $F$ & 19 & 10 & 8 & 2 & 3 \\
\hline & $\%$ & 45 & 24 & 18 & 5 & 8 \\
\hline \multirow{2}{*}{$\begin{array}{l}\text { P.P.I education is an important } \\
\text { subject that develops pupils morally }\end{array}$} & $F$ & 17 & 13 & 4 & 0 & 8 \\
\hline & $\%$ & 41 & 30 & 9 & 0 & 20 \\
\hline
\end{tabular}

(Source: Field data, 2019)

Table 1 shows level of teacher's attitude, following the Likert scale. $55 \%$ of teachers were of the idea that PPI be taught in churches, many of them agreeing that it is never possible to teach all topics in P.P.I because of inadequate resources. $52 \%$ of the teachers strongly disagreed that programme of pastoral instruction has overcrowded the timetable for nothing; while $48 \%$ said that instead of buying resource materials for P.P.I they could buy more materials for examinable subjects.

On the statement that teachers need in-service training and seminar courses to be able to effectively implement the P.P.I education programme, $45 \%$ strongly agreed whereas $42 \%$ of the teachers indicated that PPI is exciting and enjoyable to teach. $41 \%$ of the teachers strongly 
agreed that P.P.I education is an important subject that develops pupils morally while $41 \%$ disagreed that if PPI is not examined at K.C.P.E level then it should not be taught.

From the findings, most of the teachers (48\%) had a positive attitude towards the implementation of PPI in Catholic sponsored schools in Marakwet West Sub-County. The findings were contrary to Adongo (2009) who indicated that PPI has not been taken seriously in primary schools since it is not examined in the national examination at the end of primary school cycle. Most teachers use the period of PPI to teach subjects which are examined at national level. Many people think that pastoral instruction is an easy subject needing little teaching being a mere extension of church services and the Bible. This leads to a negative attitude towards the subject. The attitude of teachers towards a subject affects the way the programme is implemented. Some teachers in primary schools see programme of pastoral instruction as a source of disunity. These teachers think that, the most suitable people to teach pastoral instruction are pastors and priests. While others see PPI as an extra duty given to them, yet they are too heavily burdened with the pressing demands of the 8.4.4 education curriculum.

The response from the SCDE and SCQSO revealed that teacher's attitude towards PPI was the main challenge facing the teaching of PPI in Primary schools this may arise due to the fact that the subject is not examinable in the main exams. There is also the negative attitude held among many teacher's that programme of pastoral instruction is a mere extension of church services.

\section{Summary of Findings, Conclusions and Recommendations}

This section covers the summary of the findings based on the objective, conclusion and recommendation.

\section{Teachers Attitude towards the Implementation of Programme of Pastoral Instruction}

The first objective of the study was to investigate the teachers' attitude towards the implementation of PPI. Based on the objective, most teachers $55 \%$ had an attitude that PPI be taught in churches whereas $55 \%$ also agreed it is never possible to teach all topics in PPI because of lack of resources. 52\% strongly disagreed that the programme for pastoral instruction had overcrowded timetable for nothing and yet it is not examinable at the end of the course while $48 \%$ said that instead of buying materials for PPI they buy more materials for examinable subjects. $45 \%$ were in agreement that teachers need in service training to enable them to implement PPI effectively.

\section{Conclusions of the Study}

For the teachers to deliver effectively the management could look into their welfare and needs, the government through the ministry of education could look into the incentives of the teachers and harmonize them accordingly, a well-motivated teacher will work tirelessly to deliver the content in examinable subjects as well as the non-examinable ones such as the Programme for Pastoral Instruction.

\section{Recommendations of the Study}

There is need for teachers to undergo training, this is based on the fact that teachers who have adequate training on instructional resource use influence pre-school learners' achievement in both examinable subjects as well as non-examinable. 


\section{References}

Adongo, J. O. (2013). Does Education Influence Clean Tech Venture Capital and Private Equity Exits in Africa?

Avramidis, E., \& Kalyva, E. (2007). The influence of teaching experience and professional development on Greek teachers' attitudes towards inclusion. European journal of special needs education, 22(4), 367-389.

Ball, C., Huang, K. T., Cotten, S. R., Rikard, R. V., \& Coleman, L. O. (2016). Invaluable values: An expectancy-value theory analysis of youths' academic motivations and intentions. Information, Communication \& Society, 19(5), 618-638.

Bissessar, C. S. (2014). Facebook as an informal teacher professional development tool. Australian Journal of Teacher Education, 39(2), 9-13.

Cheruiyot, P. (2011). Sponsor meddling affects schools. Special Report, Daily Nation

Cohen, A. (2007). Commitment before and after: An evaluation and reconceptualization of organizational commitment. Human resource management review, 17(3), 336-354.

Dartey-Baah, K., \& Amoako, G. K. (2011). Application of Frederick Herzberg's Two-Factor theory in assessing and understanding employee motivation at work: a Ghanaian Perspective. European Journal of Business and Management, 3(9), 1-8.

Gikandi, J. W. (2015). Towards a theory of formative assessment in online higher education. In Handbook of research on educational technology integration and active learning 3(2) 292-316).

Gross, J. J. (2011). Emotion regulation in adulthood: Timing is everything. Current directions in psychological science, 10(6), 214-219.

Herzberg, F. (2005). Motivation-hygiene theory. Organizational behavior one: Essential theories of motivation and leadership, eds JB Miner, ME Sharpe Inc, New York, 2(4) 6174.

Kimani, E. N. (2014). Challenges in quality control for postgraduate supervision. International Journal of Humanities Social Sciences and Education, 1(9), 63-70.

Klein, W. W., Blomberg, C. L., \& Hubbard Jr, R. L. (2017). Introduction to biblical interpretation. Zondervan Academic.

Koech, J. C. (2014). An inquiry into the attitude of students in secondary schools towards Christian religious education in Kapsabet division, Nandi County, Kenya. Journal of Emerging Trends in Educational Research and policy studies, 1(1), 21-29.

Kothari, C. R. (2012). Research methodology: An introduction. Research Methodology: Methods and Techniques, 9(1), 418-425.

Lai, C. (2009). Motivating employees through incentive programs. Harvard Business Review Press. London.

Lakshmi, S., \& Mohideen, M. A. (2013). Issues in Reliability and Validity of Research. International journal of management research and reviews, 3(4), 2752.

Larson, E. M. (2019). Civic and Religious Education in Manado, Indonesia: The case of God v. John Rawls? Ethics, 105(3), 468-496.

Mabeya, T. M., Ndiku, J. M., \& Njino, J. (2010). Role of church sponsor in management of secondary schools: Impact on academic performance and conflict concerns in Kenya. International Journal of Educational Administration and Policy Studies, 2(2), 031038

Malik, M. E., \& Naeem, B. (2013). Towards understanding controversy on Herzberg theory of motivation. World Applied Sciences Journal, 24(8), 1031-1036.

Maslow, A. H. (1943). Preface to motivation theory. Psychosomatic medicine. 
Meece, J. L., Anderman, E. M., \& Anderman, L. H. (2016). Classroom goal structure, student motivation, and academic achievement. Annu. Rev. Psychol., 57, 487-503.

Mitchell, M. L., \& Jolley, J. M. (2012). Research design explained. Cengage Learning.

Mohamad, M. M., Sulaiman, N. L., Sern, L. C., \& Salleh, K. M. (2015). Measuring the validity and reliability of research instruments. Procedia-Social and Behavioral Sciences, 204, 164-171.

Mugenda, O. M., \& Mugenda, A. G. (1999). Research methods: Quantitative and qualitative approaches. Act's press. Nairobi.

Munishi, J. E. (2016). Primary Teacher Education CRE. Nairobi. East African

Muthamba, J. (2017). Implementation of moral education in Kenyan schools: a study of selected catholic schools from Kitui Central Deanery. International Journal of Research in Management, 6(6), 17-32.

Nderitu, M. W. (2020). The Influence of Strategic Implementation Practices on Students' Academic Performance in Public Secondary Schools. Journal of Educational and Social Research, 4(1), 289-289. Newspaper, 13th March.

Nwanchukwu, O. (2006). Poverty Eradication, what hope for Nigeria. Targeting Communication for Effective Poverty Alleviation. World Bank African Region, 1(2) 68-71.

Odongo, S. A. (2009). The implementation of the Programme of Pastoral Instruction (PPI) in Primary Schools within Eldoret Municipality. Sapiens, 1(2), 28-43. Publishers.

Ratzburg, W. H. (2013). McClelland's achievement motivation theory. In the Thematic Apperception Test (TAT) and McClelland's Achievement Motivation Theory.

Rivas, S. C. (2002). The Interwoven Relationship of Religion, Theology, and Ethics with Secular Knowledge. Cross Currents, 22(4), 381-397.

Sylvia, R. D., \& Hutchison, T. (1985). What makes Ms. Johnson teach? A study of teacher motivation. Human relations, 38(9), 841-856.

Vansteenkiste, M., Aelterman, N., Haerens, L., \& Soenens, B. (2019). Seeking stability in stormy educational times: A need-based perspective on (de) motivating teaching grounded in self-determination theory. In Motivation in Education at a Time of Global Change. Emerald Publishing Limited.

Walkington, J. (2012). A process for curriculum changes in engineering education. European Journal of Engineering Education, 27(2), 133-148.

Winston, K. (2008). Bead One, Pray Too: A Guide to Making and Using Prayer. Beads. Church Publishing, Inc. 